\title{
Article \\ Impact of Enzymatic Hydrolysis and Heat Inactivation on the Physicochemical Properties of Milk Protein Hydrolysates
}

\author{
Alice Gruppi ${ }^{1,2}$, Maria Dermiki $\left.{ }^{2,3}{ }^{(}\right)$, Giorgia Spigno ${ }^{1, *}\left(\mathbb{C}\right.$ and Richard J. FitzGerald ${ }^{2} \mathbb{C}$ \\ 1 Department for Sustainable Food Process (DiSTAS), Università Cattolica del Sacro Cuore, \\ Via Emilia Parmense 84, 29122 Piacenza, Italy; alice.gruppi@unicatt.it \\ 2 Department of Biological Sciences, School of Natural Sciences, University of Limerick, \\ V94 T9PX Limerick, Ireland; Dermiki.Maria@itsligo.ie (M.D.); dick.fitzgerald@ul.ie (R.J.F.) \\ 3 Faculty of Science, Institute of Technology Sligo, F91 YW50 Sligo, Ireland \\ * Correspondence: giorgia.spigno@unicatt.it
}

check for updates

Citation: Gruppi, A.; Dermiki, M.; Spigno, G.; FitzGerald, R.J. Impact of Enzymatic Hydrolysis and Heat Inactivation on the Physicochemica Properties of Milk Protein Hydrolysates Foods 2022, 11, 516. https://doi.org/ $10.3390 /$ foods 11040516

Academic Editors: Federico Casanova and Michela Verni

Received: 10 January 2022

Accepted: 8 February 2022

Published: 11 February 2022

Publisher's Note: MDPI stays neutral with regard to jurisdictional claims in published maps and institutional affiliations.

Copyright: (c) 2022 by the authors. Licensee MDPI, Basel, Switzerland. This article is an open access article distributed under the terms and conditions of the Creative Commons Attribution (CC BY) license (https:// creativecommons.org/licenses/by/ $4.0 /)$.

\begin{abstract}
This study determined the physicochemical properties (apparent viscosity ( $\eta_{\text {app }}$ ), turbidity $\left(\mathrm{A}_{550 \mathrm{~nm}}\right)$, particle size and molecular mass distribution) of hydrolysates generated from whey protein concentrate (WPC), milk protein concentrate (MPC) and sodium caseinate ( $\mathrm{NaCN}$ ), following incubation with Debitrase HYW20 $0^{\mathrm{TM}}$ and Prolyve ${ }^{\mathrm{TM}}$ at $50{ }^{\circ} \mathrm{C}$, pH 7.0 for 1 and $4 \mathrm{~h}$, before and after heat inactivation $\left(80^{\circ} \mathrm{C}\right.$ for $10 \mathrm{~min}$ ). The degree of hydrolysis (DH) increased with incubation time, giving values of $6.56 \%, 8.17 \%$ and $9.48 \%$, following $1 \mathrm{~h}$ hydrolysis of WPC, MPC and NaCN with Debitrase HYW20 ${ }^{\mathrm{TM}}$, and $12.04 \%, 15.74 \%$ and $17.78 \%$, respectively, following $4 \mathrm{~h}$ incubation. These DHs were significantly higher compared to those obtained following $4 \mathrm{~h}$ incubation with Prolyve ${ }^{\mathrm{TM}}$. Hydrolysis with Debitrase HYW20 ${ }^{\mathrm{TM}}$ gave $>40 \%$ of peptides with molecular masses $<1 \mathrm{kDa}$ for all substrates, which was higher than the value obtained following hydrolysis with Prolyve ${ }^{\mathrm{TM}}$. The effect of hydrolysis on the physicochemical properties was substrate dependent, since $\eta_{\text {app }}$ decreased in WPC and $\mathrm{NaCN}$ hydrolysates, particle size decreased for all the substrates, with aggregate formation for MPC, and turbidity decreased in WPC and MPC hydrolysates, while it increased in NaCN hydrolysates. The physical properties of the hydrolysates were influenced by the enzyme thermal inactivation step in a DH-dependent manner, with no significant effect on turbidity and viscosity for hydrolysates at higher DHs.
\end{abstract}

Keywords: degree of hydrolysis; milk protein concentrate; molecular mass distribution; sodium caseinate; turbidity; viscosity; whey protein

\section{Introduction}

Dairy proteins are commonly used as ingredients in complex food systems, either for structuring or for nutritional purposes [1]. The enzymatic hydrolysis of dairy proteins can enhance their techno- and bio-functional properties [2-5]. Whey protein concentrate (WPC), milk protein concentrate (MPC) and sodium caseinate $(\mathrm{NaCN})$ represent some of the most used, and therefore, the most extensively studied dairy protein ingredients. Specifically, $\mathrm{NaCN}$ is utilised due to its foaming and emulsifying properties [6], while whey protein ingredients are utilised for their gelation and emulsification properties, and their good solubility at acid $\mathrm{pH}[7,8]$. The application of MPCs [9], with high protein contents $(>70 \%)$, may be impacted by the variability in their solubility properties [10-12].

Milk protein hydrolysates exhibit improved techno-functional properties compared to the intact proteins, thereby enhancing their applications as ingredients in different food preparations. Several studies have demonstrated an increase in protein solubility following enzymatic hydrolysis [13-17], as reported by Ryan et al. [18] who found that the hydrolysis of milk protein isolate, with Flavourzyme, Neutrase and Protamex, led to increased solubility at $\mathrm{pH}$ 4.0-7.0. Moreover, hydrolysis can lead to significant improvements in the foaming, gelling and emulsifying properties of whey protein hydrolysates [19-22] of 
casein hydrolysates [23] and milk protein hydrolysates $[24,25]$ in comparison with the intact proteins. This improvement in functional properties may be attributed to changes in the secondary structure and to a decrease in molecular mass following hydrolysis [26]. In many cases, enzymatic hydrolysis of milk proteins can lead to improved bio-functional properties, due to the formation of peptides with, e.g., angiotensin converting enzyme-inhibitory activity, antidiabetic or antimicrobial activities [2], which are not biologically active when they are in the parent protein [2]. Whey proteins can also give rise to bioactive peptides once the primary structure is hydrolysed; these peptides can display different bioactivities, such as antioxidative activity, be more effective in treating tumours in some cancers and can inhibit ACE activity in vitro [27].

The properties of milk protein hydrolysates depend on the conditions under which they have been generated $[3,4]$, such as the enzymes used, since different enzymes, depending on their specificity, will result in the formation of peptides with varying molecular masses and hydrophobicity [3]. Furthermore, hydrolysate properties are dependent on the $\mathrm{pH}$ employed during hydrolysis [28], hydrolysis time, incubation temperature [29], enzyme to substrate ratio [30] and total solids [31]. During their manufacture, hydrolysates are usually subjected to an enzyme heat inactivation step, prior to concentration and spray-drying. Therefore, when generating hydrolysates, it is important to consider the impact of both the hydrolysis and heat inactivation conditions on the properties of the hydrolysates generated, prior to and following drying. This is due to the fact that changes in the viscosity, turbidity and the formation of aggregates, during hydrolysis and subsequent enzyme thermal inactivation, can affect the heat and mass transfer properties during various processing steps. Therefore, it is expected that hydrolysis parameters, such as the enzyme employed, the duration of hydrolysis along with heat inactivation, will impact the properties of the hydrolysates generated using different substrates.

The aim of this study was to investigate the impact of the enzyme preparation and incubation time on the physicochemical properties $\left(\mathrm{DH}, \eta_{\text {app }}\right.$, turbidity $\left(\mathrm{A}_{550 \mathrm{~nm}}\right)$, particle size and molecular mass distribution) of hydrolysates, generated from WPC, MPC and NaCN using Debitrase ${ }^{\mathrm{TM}}$ and Prolyve ${ }^{\mathrm{TM}}$. The impact of enzyme heat inactivation on hydrolysate particle size, $\eta_{\text {app }}$ and turbidity was also investigated.

\section{Materials and Methods}

\subsection{Materials}

The milk protein substrates $\mathrm{NaCN}$ (Arrabawn Co-Operative Creamery, Nenagh, Ireland), MPC (Kerry Ingredients, Listowel, Ireland) and WPC (Carbery, Ballineen, Ireland) had protein contents of $85 \%, 84 \%$ and $82 \%(w / w)$, respectively, and were kindly provided by the above manufacturers. The food-grade proteolytic preparation Debitrase HYW20 ${ }^{\mathrm{TM}}$ was kindly provided by Rhodia Ltd. (Cheshire, UK), and Prolyve $1000^{\mathrm{TM}}$ was provided by Lyven Enzymes Industrielles (Caen, France). 2,4,6-Trinitrobenzenesulfonic acid (TNBS) was obtained from Pierce Biotechnology (Medical Supply, Dublin, Ireland) and all other chemicals and reagents were purchased from Sigma Chemical Company Ltd. (Dublin, Ireland).

\subsection{Methods}

\subsubsection{Generation of Enzymatic Hydrolysates}

The hydrolysis procedure was based on the protocol employed by Dermiki and FitzGerald [29] with some adaptations. Substrate suspensions with different concentrations were prepared based on their solubility. MPC and $\mathrm{NaCN}$ were dissolved at $8 \%(w / w)$ while WPC was reconstituted at $10 \%(w / w)$ in distilled water at room temperature and then gently stirred at $5^{\circ} \mathrm{C}$ for $16 \mathrm{~h}$ to aid hydration. Before hydrolysis, the temperature of the substrate samples was adjusted to $50^{\circ} \mathrm{C}$ and maintained at this temperature for $1 \mathrm{~h}$ prior to initiating the hydrolysis reaction. The $\mathrm{pH}$ of the substrate solutions was adjusted to $\mathrm{pH} 7.0$ using $0.5 \mathrm{M} \mathrm{NaOH}$. The enzyme (Debitrase HYW20 ${ }^{\mathrm{TM}}$ or Prolyve $1000^{\mathrm{TM}}$ ) was added at an enzyme to substrate ratio (E:S) of $0.5 \%(v / w)$ while hydrolysis was carried out at $50{ }^{\circ} \mathrm{C}$, using a magnetic stirrer (Fisherbrand, Fisher Scientific, Dublin, Ireland) set at 
$500 \mathrm{rpm}$ and the $\mathrm{pH}$ of the hydrolysis reaction was controlled at $\mathrm{pH} 7.0$ using a $\mathrm{pH}$-stat (Titrando 843, Tiamo 1.4 Metrohm, Dublin, Ireland) by the addition of $0.5 \mathrm{M} \mathrm{NaOH}$. Control samples of MPC, WPC and $\mathrm{NaCN}$, without enzymes, were included in the experimental plan. The volume of all samples (hydrolysates and unhydrolyzed protein samples without the addition of enzyme) was adjusted with distilled water to achieve the same final total solids concentration (7.99\% $(w / w)$ for $\mathrm{NaCN}$ and MPC; and 9.99\% for WPC). Enzyme inactivation was conducted by heating the solutions at $80{ }^{\circ} \mathrm{C}$ for $10 \mathrm{~min}$ in a water bath as reported by Dermiki and FitzGerald [29]. Hydrolysates were then frozen and stored at $-20{ }^{\circ} \mathrm{C}$ until further analysis, unless stated otherwise. Figure 1 provides a schematic overview of the experimental approach employed.

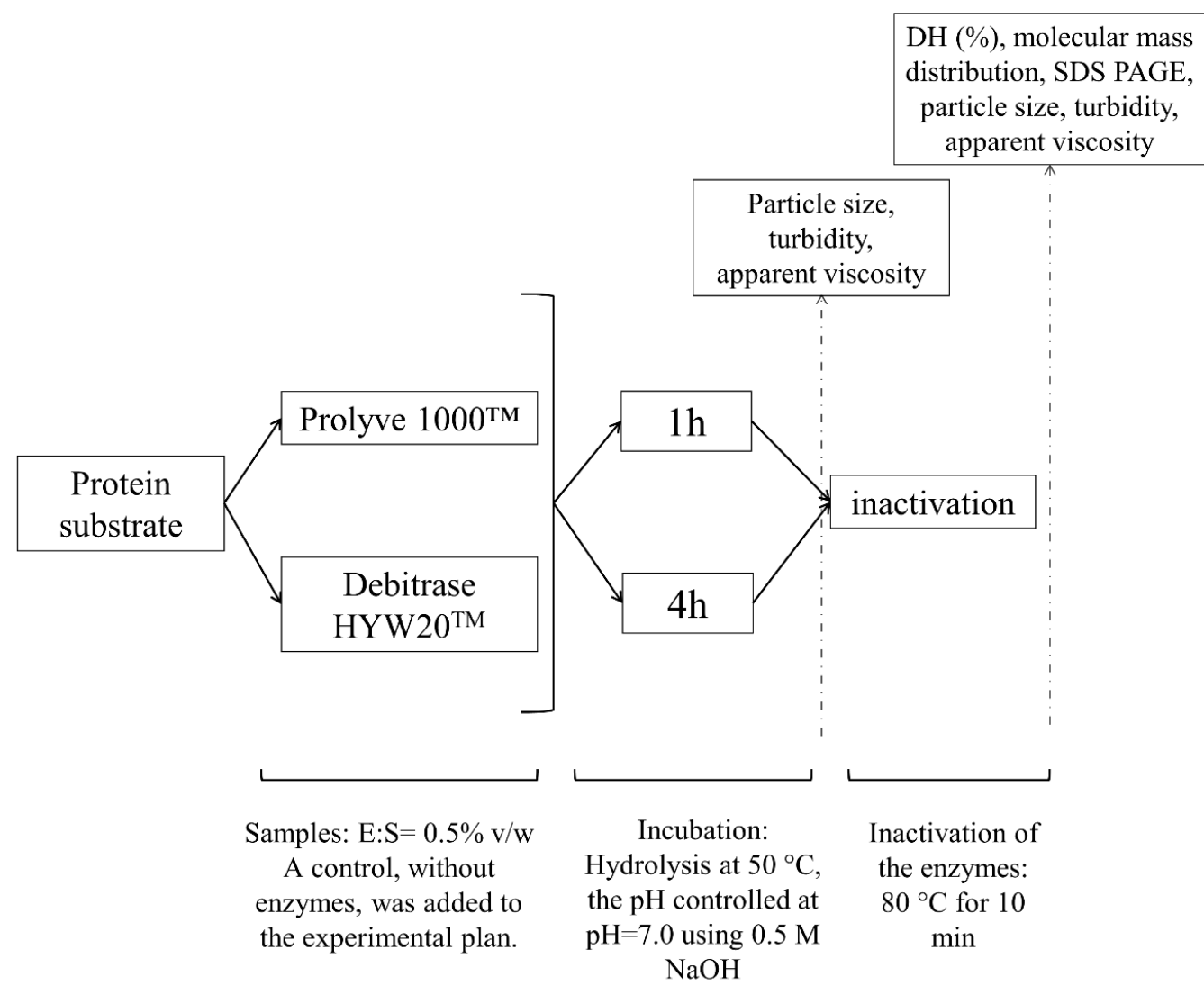

Figure 1. Schematic representation of the experimental approach. The initial substrate concentration for milk protein concentrate (MPC) and sodium caseinate $(\mathrm{NaCN})$ was $8 \%(w / w)$ total solids and for whey protein concentrate (WPC) it was $10 \%(w / w)$ total solids in distilled water. Note: $\mathrm{DH}$ : degree of hydrolysis; E:S: enzyme to substrate ratio $(v / w)$, SDS PAGE: Sodium dodecyl sulphate polyacrylamide gel electrophoresis.

Particle size distribution, turbidity and $\eta_{\text {app }}$ analyses were determined before and after heat inactivation on the day of hydrolysate production while DH and molecular mass distribution analyses were performed on the heat-treated hydrolysates (Figure 1).

\subsubsection{Determination of $\mathrm{DH}$}

The spectrophotometric TNBS assay was used to determine the DH (\%) as reported by Adler-Nissen [32] with the modifications of Le Maux et al. [28]. Samples (hydrolysed and unhydrolyzed control samples after heat inactivation) were diluted in $1 \%(w / v)$ SDS to a final protein concentration/protein equivalent of $5 \%(w / v)$ and prior to incubation at $50{ }^{\circ} \mathrm{C}$ for $30 \mathrm{~min}$. Then, $10 \mu \mathrm{L}$ of the test hydrolysate samples and leucine standards $(0,2,5$, $7,14,21,28$ and $56 \mathrm{mg}$ of nitrogen/L) were loaded onto a 96-well plate with $160 \mu \mathrm{L}$ TNBS working solution $\left(0.05 \%\right.$ TNBS $(w / v)$ and a $1: 1$ mixture of preheated $\left(50{ }^{\circ} \mathrm{C}\right)$ water and 
$0.2125 \mathrm{M}$ phosphate buffer $\mathrm{pH}$ 8.2). The plate was incubated at $50{ }^{\circ} \mathrm{C}$ for $1 \mathrm{~h}$ in a Synergy ${ }^{\mathrm{TM}}$ HT plate reader (BioTek Instruments Limited, Bedfordshire, UK) and the absorbance at 420 $\mathrm{nm}$ was recorded. The DH was calculated using Equation (1), as follows:

$$
\mathrm{DH}(\%)=\frac{\mathrm{AN}_{\text {sample }}-\mathrm{AN}_{\text {unhydrolysed sample }}}{\mathrm{Npb}}
$$

where $\mathrm{AN}_{\text {sample }}$ is the amino nitrogen content of the protein hydrolysate ( $\mathrm{mg} / \mathrm{g}$ protein), $\mathrm{AN}_{\text {unhydrolyzed sample }}$ is the amino nitrogen content of the protein substrate before hydrolysis ( $\mathrm{mg} / \mathrm{g}$ protein) and $\mathrm{Npb}$ is the nitrogen content of the peptide bonds in the protein substrate (mg/g protein); values of 100, 123.3 and 112.1, respectively, were used for MPC [24], WPC [7] and NaCN [33]. Analysis was conducted in triplicate $(n=3)$.

\subsubsection{Particle Size Distribution}

Particle size distribution of the hydrolysates and controls was determined by laser light scattering as described by Le Maux et al. [34].

A Mastersizer 2000 with a Hydro 2000S dispersion system (Malvern Instruments, Worcestershire, UK) was used to analyse the particle sizes of the samples. Laser obscuration between $5-10 \%$ was obtained using the dispersion unit before each measurement. The particle and the dispersant refractive index used were 1.52 and 1.33, respectively. Each sample was measured in triplicate. Analysis of the results was performed using the generalpurpose model available from the Malvern software. The particle size distributions were expressed as the cumulative weight $(\%)$ per volume moment mean diameter of the particles $\left(\mathrm{D}_{3,2} \mu \mathrm{m}\right)$.

\subsubsection{Molecular mass Distribution}

Gel permeation high-performance liquid chromatography (GP-HPLC) was used to determine the molecular mass distribution of the samples at a concentration of $0.25 \%(w / v)$ protein/protein equivalent as described by Nongonierma and FitzGerald [35]. Samples were filtered through $0.2 \mu \mathrm{m}$ PTFE filters prior to injection. Aliquots $(20 \mu \mathrm{L})$ of diluted sample were injected onto a TSK G2000 SW separating column $(600 \times 7.5 \mathrm{~mm}$ ID) (Tosoh 157 Bioscience, Stuttgart, Germany). Separation took place by isocratic elution using $0.1 \%(v / v)$ trifluoroacetic acid (TFA), 30\% $(v / v)$ acetonitrile in $\mathrm{H}_{2} \mathrm{O}$, at a flow rate of $1 \mathrm{~mL} / \mathrm{min}$. Detector response was monitored at $214 \mathrm{~nm}$ [35]. A calibration curve was generated using the average retention times of the standards (BSA $(67,500 \mathrm{Da}), \beta$-lactoglobulin $(36,000 \mathrm{Da})$, $\alpha$-lactalbumin (14,200 Da), aprotinin (6500 Da), bacitracin (1400 Da), Leu-Trp-Met-Arg-OH (605 Da), Asp-Glu (262 Da), Tyr (181 Da)). Molecular mass distributions were obtained by integrating the area under the curve corresponding to the average retention time of the different molecular masses at 10, 5 and $1 \mathrm{kDa}$.

\subsubsection{Turbidity $\left(\mathrm{A}_{550 \mathrm{~nm}}\right)$ Measurements}

Turbidity was evaluated as described by O'Loughlin et al. [36]. Samples were diluted to $0.1 \%(w / v)$ protein/protein equivalent with distilled water and vortexed to prevent immediate separation, the absorbance $(200 \mu \mathrm{L}$ sample volume) was then read at $550 \mathrm{~nm}$ at room temperature using a Synergy ${ }^{\mathrm{TM}} \mathrm{HT}$ plate reader. All samples were analysed in triplicate $(\mathrm{n}=3)$.

\subsubsection{Determination of Apparent Viscosity ( $\left.\eta_{\mathrm{app}}\right)$}

The samples were equilibrated at $50^{\circ} \mathrm{C}$ and the $\eta_{\text {app }}$ was measured using a Brookfield DVII+ LV (Brookfield Engineering Laboratories, Middleboro, MA, USA) viscometer, fitted with an ultra-low adaptor (ULA). Measurements were conducted at a defined shear rate, i.e., $112 \mathrm{~s}^{-1}$ (or rotational speed of the spindle at $100 \mathrm{rpm}$ ). The ULA adaptor was connected to a Brookfield refrigerated circulating water bath (model TC-500) by an ULA-40Y water jacket in order to control the temperature at $50{ }^{\circ} \mathrm{C}$ during measurements as described by Dermiki and FitzGerald [29]. 


\subsubsection{Statistical Analysis}

All statistical analyses were conducted using XLStat statistical software (XLStat, 2020.1.3.65324, Addinsoft, New York, NY, USA) [37]. Values presented are the mean of three replicates \pm standard deviation, unless otherwise stated. The standardised residuals were calculated and were normally distributed. Normality was tested using the Shapiro-Wilk test which is best suited for small sample sizes. Data were also tested for homogeneity by plotting scatterplots of the residuals against predictors. These tests were all conducted as part of the ANOVA analysis using XLStat [37]. One-way analysis of variance (ANOVA), two-way ANOVA or full factorial design was used to test the effect of one, two or more factors (enzyme, incubation time, heated or unheated) on the responses studied, respectively. When significance was noted, comparison of means was conducted by employing a Tukey post-hoc test. Significance was determined at $p<0.05$.

\section{Results and Discussion}

\subsection{Hydrolysis of Milk Protein Substrates}

The following two commercially available proteolytic preparations were used in the current study: Debitrase HYW20 $0^{\mathrm{TM}}$ and Prolyve $1000^{\mathrm{TM}}$. Debitrase HYW20 ${ }^{\mathrm{TM}}$ is an enzyme preparation derived from Aspergillus oryzae and Bacillus spp. (rich in exopeptidase and with proteases), which has been shown to produce hydrolysates with reduced bitterness [38,39], while Prolyve $1000^{\mathrm{TM}}$ is a Bacillus licheniformis proteinase, which does not cause gelation [31] and has also been reported to show decreased bitterness compared to Alcalase ${ }^{\mathrm{TM}}$, another commonly used Bacillus licheniformis proteinase [35].

According to Cui et al. [17], the treatment with Protamex, which has both endo- and exo-protease activity, led to the hydrolysates with the lowest levels of bitterness, compared with Alcalase (which preferentially hydrolyses peptide bonds containing aromatic amino acid residues), and Flavouryme (which is produced from Aspergillus oryzae, as for Debitrase HYW20 $\left.{ }^{\mathrm{TM}}\right)$. However, MPC treated with Alcalase presented higher DH than those obtained by Protamex and Flavourzyme.

Table 1 shows the DHs obtained for the three substrates (WPC, MPC and $\mathrm{NaCN}$ ) after incubation for 1 and $4 \mathrm{~h}$ with Debitrase and Prolyve. A two-way ANOVA was conducted to investigate the effect of enzyme and incubation time on the DH for each substrate. As expected from previous studies [40], there was an effect of incubation time on DH, with higher DHs being observed after $4 \mathrm{~h}$ incubation for all substrates with both enzymes. When considering the effect of the enzyme, no effect was observed after $1 \mathrm{~h}$ incubation with a DH of approximately $7 \%$ being reached with both enzymes for WPC and MPC, whereas in the case of $\mathrm{NaCN}$, a higher $\mathrm{DH} \%(9.48 \pm 0.88)$ was observed on incubation with Debitrase. When comparing the three substrates, a higher $\mathrm{DH}$ was observed for $\mathrm{NaCN}$ and MPC after $4 \mathrm{~h}$ incubation (17.78 \pm 1.00 and $15.74 \pm 1.36$, respectively, with Debitrase), possibly due to the fact that caseins are more susceptible to hydrolysis compared to whey proteins [22] and these two substrates predominantly contain casein. The higher susceptibility of casein to hydrolysis could be attributed to its open or disordered structure, while whey proteins have a globular structure in their native state [41].

Prolyve is a Bacillus licheniformis proteolytic preparation with a broad substrate specificity, which may explain the relatively high DH (around 7\%) obtained with all three substrates, even after $1 \mathrm{~h}$ of incubation. This enzyme preparation preferentially cleaves at the carboxyl side of hydrophobic amino acid residues [42]. Debitrase HYW20 contains Aspergillus oryzae exopeptidase activity, allowing it to generate hydrolysates rich in free amino acids. Moreover, due to the presence of proteases from Bacillus spp., Debitrase has broad specificity [43], resulting in relatively high $\mathrm{DH}$ values. When comparing the $\mathrm{DH}$ of the hydrolysates generated after $4 \mathrm{~h}$ of incubation, Debitrase resulted in higher $\mathrm{DH}$ values compared to Prolyve with all substrates. These findings are in agreement with those of Spellman et al. [7], who reported higher DH values for whey protein hydrolysates generated using Debitrase, compared to those generated using Alcalase, which is also a Bacillus licheniformis proteinase like Prolyve. In other studies [44], the hydrolysis of $\mathrm{NaCN}$ 
with Debitrase resulted in a relatively low DH compared to a range of other enzymes; however, the $\mathrm{DH}$ was calculated from the volume of $\mathrm{NaOH}$ consumed during hydrolysis, whereas in the current study, it was determined using the TNBS method. Moreover, different reaction times and $\mathrm{pH}$ values were employed in the two studies. There appears to be no information on the hydrolysis of MPC using Debitrase or Prolyve. As previously mentioned, Cui et al. [17] hydrolysed MPC using Alcalase, Protamex and Flavourzyme, and obtained DH around $15.3 \%$ with Alcalase after $2 \mathrm{~h}$ of hydrolysis. This value is significantly higher than the DH obtained in the current study using Prolyve, an enzyme with similar activity to Alcalase. These differences could be due to the different ways of measuring the DH (TNBS vs. o-phthaldialdehyde (OPA)) or possibly different hydrolysis conditions of $\mathrm{pH}$ and temperature.

Table 1. Degree of hydrolysis ( $\mathrm{DH}, \%)$ of milk protein concentrate (MPC), whey protein concentrate (WPC) and sodium caseinate $(\mathrm{NaCN})$ hydrolysates as a function of enzyme preparation, Prolyve $1000^{\mathrm{TM}}$ (Pro) or Debitrase HYW20 ${ }^{\mathrm{TM}}$ (Deb), and incubation time. Values presented are mean \pm standard deviation $(\mathrm{n}=3)$.

\begin{tabular}{cccc}
\hline \multirow{2}{*}{ Substrate } & Enzyme & \multicolumn{2}{c}{ DH (\%) at Different Incubation Times } \\
\cline { 2 - 4 } & & $\mathbf{1 ~ h}$ & $\mathbf{4} \mathbf{h}$ \\
\hline \multirow{3}{*}{ MPC } & Control & $0.92 \pm 0.21^{\mathrm{e}}$ & $1.04 \pm 0.37^{\mathrm{e}}$ \\
& Pro & $7.05 \pm 0.40^{\mathrm{c}}$ & $11.65 \pm 0.98^{\mathrm{b}}$ \\
& Deb & $8.17 \pm 0.58^{\mathrm{c}}$ & $15.74 \pm 1.36^{\mathrm{a}}$ \\
\hline \multirow{2}{*}{$\mathrm{WPC}$} & Control & $2.11 \pm 0.15^{\mathrm{d}}$ & $2.26 \pm 0.07^{\mathrm{d}}$ \\
& Pro & $7.12 \pm 0.50^{\mathrm{c}}$ & $9.54 \pm 1.09^{\mathrm{b}}$ \\
& Deb & $6.56 \pm 0.38^{\mathrm{c}}$ & $12.04 \pm 0.73^{\mathrm{a}}$ \\
\hline \multirow{2}{*}{$\mathrm{NaCN}$} & Control & $0.30 \pm 0.26^{\mathrm{e}}$ & $0.66 \pm 0.26^{\mathrm{e}}$ \\
& Pro & $7.18 \pm 0.67^{\mathrm{d}}$ & $11.67 \pm 0.67^{\mathrm{b}}$ \\
& deb & $9.48 \pm 0.88^{\mathrm{c}}$ & $17.78 \pm 1.00^{\mathrm{a}}$ \\
\hline
\end{tabular}

Note: ${ }^{a}, b, c, d, e$ superscripts with a different letter across each substrate represent means which are significantly different at a significance level $p<0.05$ as determined using two-way ANOVA and post-hoc Tukey test.

Protein hydrolysis was further confirmed using GP-HPLC, as seen in Figure 2, showing the breakdown of high molecular mass $(>10 \mathrm{kDa})$ components representing the intact protein during the hydrolysis process. The molecular mass distribution of the peptides generated during hydrolysis may impact the nutritional properties of the hydrolysates, e.g., their bioavailability and digestibility [45], along with techno-functional properties, such as solubility, emulsification, foaming and gelation. This has been related to lower molecular weight components exhibiting better interfacial diffusivity compared to large biopolymers [46], even though higher DH values may result in the loss of emulsifying properties $[47,48]$.

As seen in Figure 2, enzymatic treatment clearly results in a decrease in molecular mass, with higher percentages of lower molecular mass components in the hydrolysates compared to the corresponding controls. As expected from the results of the DH analyses presented in Table 1, all the substrates show a higher proportion of lower molecular mass components after $4 \mathrm{~h}$ incubation. As already mentioned, Debitrase contains exopeptidase activity, and its hydrolysates are expected to contain higher concentrations of short peptides/free amino acids. On the other hand, hydrolysis by B. licheniformis proteases, such as Prolyve, is expected to release peptides without free amino acids [49]. Debitrase hydrolysates had a higher proportion of components with lower molecular mass $(<1 \mathrm{kDa})$ compared to Prolyve hydrolysates, e.g., in the case of $\mathrm{NaCN}$ (56\% versus 49\%) and WPC ( $43.5 \%$ versus $40 \%$ ). However, in the case of the MPC hydrolysates, both enzymes produced a similar amount $(\sim 50 \%)$ of components, with a molecular mass $<1 \mathrm{kDa}$. The observation that the percentage of molecules with low molecular mass is lower in WPC hydrolysates is in agreement with the differences observed in DH (see Table 1) and the fact that casein 
is more susceptible to hydrolysis compared to whey proteins. Moreover, the relatively high percentage of low molecular weight compounds in the NaCN and MPC hydrolysates is in agreement with the findings of McDonagh and FitzGerald [43], who reported high percentages of low molecular weight components $(<3 \mathrm{kDa})$ when Debitrase was used.

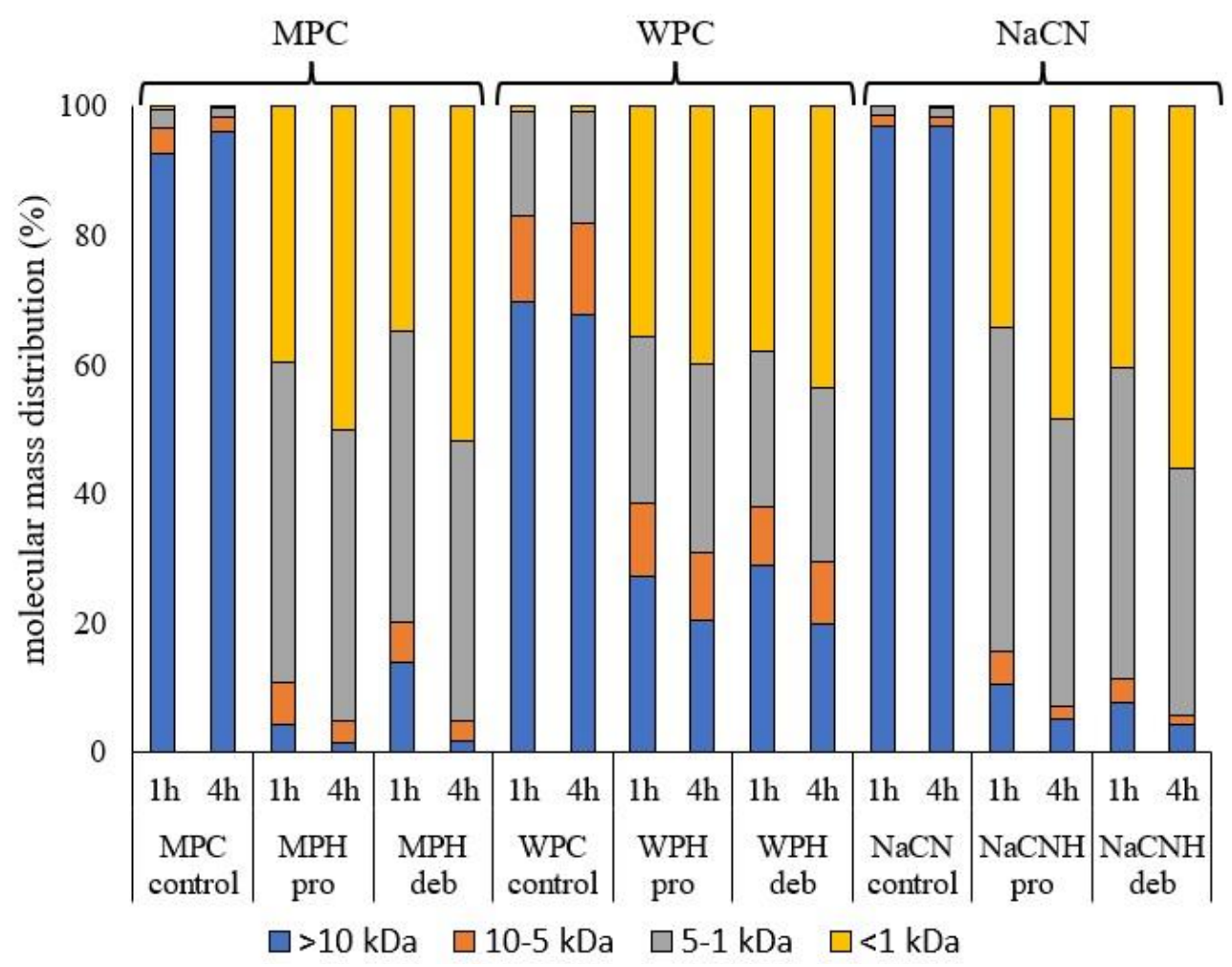

Figure 2. Molecular mass distribution profiles of the unhydrolyzed whey protein concentrate (WPC), sodium caseinate $(\mathrm{NaCN})$ and milk protein concentrate (MPC) control samples and their corresponding hydrolysates (respectively, WPH, $\mathrm{NaCNH}$ and $\mathrm{MPH}$ ) generated using Prolyve $1000^{\mathrm{TM}}$ (WPH pro, $\mathrm{NaCNH}$ pro, MPH pro) and Debitrase HYW20 ${ }^{\mathrm{TM}}$ (WPH deb, NaCNH deb, MPH deb) following 1 and $4 \mathrm{~h}$ incubation at $50^{\circ} \mathrm{C}$. kDa: kilo Dalton.

\subsection{Physicochemical Characteristics of the Hydrolysates \\ 3.2.1. Particle Size}

Figure 3 represents the volume moment mean diameter $\mathrm{D}[3,2]$ of particles in suspension for WPC, MPC and $\mathrm{NaCN}$, before and after hydrolysis, and after heat inactivation showing an influence of both substrate and enzyme type. For MPC, the particle size decreased with incubation time for both the hydrolysates and the intact protein. The latter may be related to the increased solubility of MPC with increasing incubation time. Moreover, at $1 \mathrm{~h}$ incubation, the particle size of the MPC hydrolysates was higher compared to the intact protein, possibly due to aggregation between the peptides in solution, while subsequent heating resulted in a decrease in D[3,2]. This was more evident at low $\mathrm{DH}$ and short incubation times for both enzymes. Cui et al. [17] reported increased particle size of hydrolysates of MPC, generated using Alcalase, Protamex and Flavourzyme, compared to the intact protein. In the study by Cui et al. [17] changes in particle size during incubation were enzyme-dependent. They had not reported, however, the effect of heat inactivation on the particle size of MPC hydrolysates. In the case of $\mathrm{NaCN}$, the particle size decreased on hydrolysis, regardless of the enzyme used, even after $1 \mathrm{~h}$ incubation. For the WPC hydrolysate, particle size decreased with incubation time for both enzymes but with no clear trend, as seen in Figure 3. This may be attributed to the observation that in most cases, the particle size distribution was neither normal nor bimodal, especially for the MPC and WPC hydrolysates, for which Figure A1 shows how the particle size distribu- 
tions changed during hydrolysis. For WPC, it was evident that the particle size decreased without aggregation during hydrolysis, with no differences due to treatment time and enzyme type. However, the heat inactivation step modified the particle size distributions, as seen in Figure 3. In the case of $\mathrm{NaCN}$, no aggregate formation was observed for the hydrolysates generated using Prolyve, especially after $4 \mathrm{~h}$ of incubation, while subsequent heating resulted in the formation of aggregates. However, in the case of $\mathrm{NaCN}$ treated with Debitrase HYW20 ${ }^{\mathrm{TM}}$, the particle size distributions were not affected by heating, as seen in Figure 3. The formation of aggregates during hydrolysis can impact the turbidity and the behaviour of hydrolysates as ingredients in complex food matrices [50].

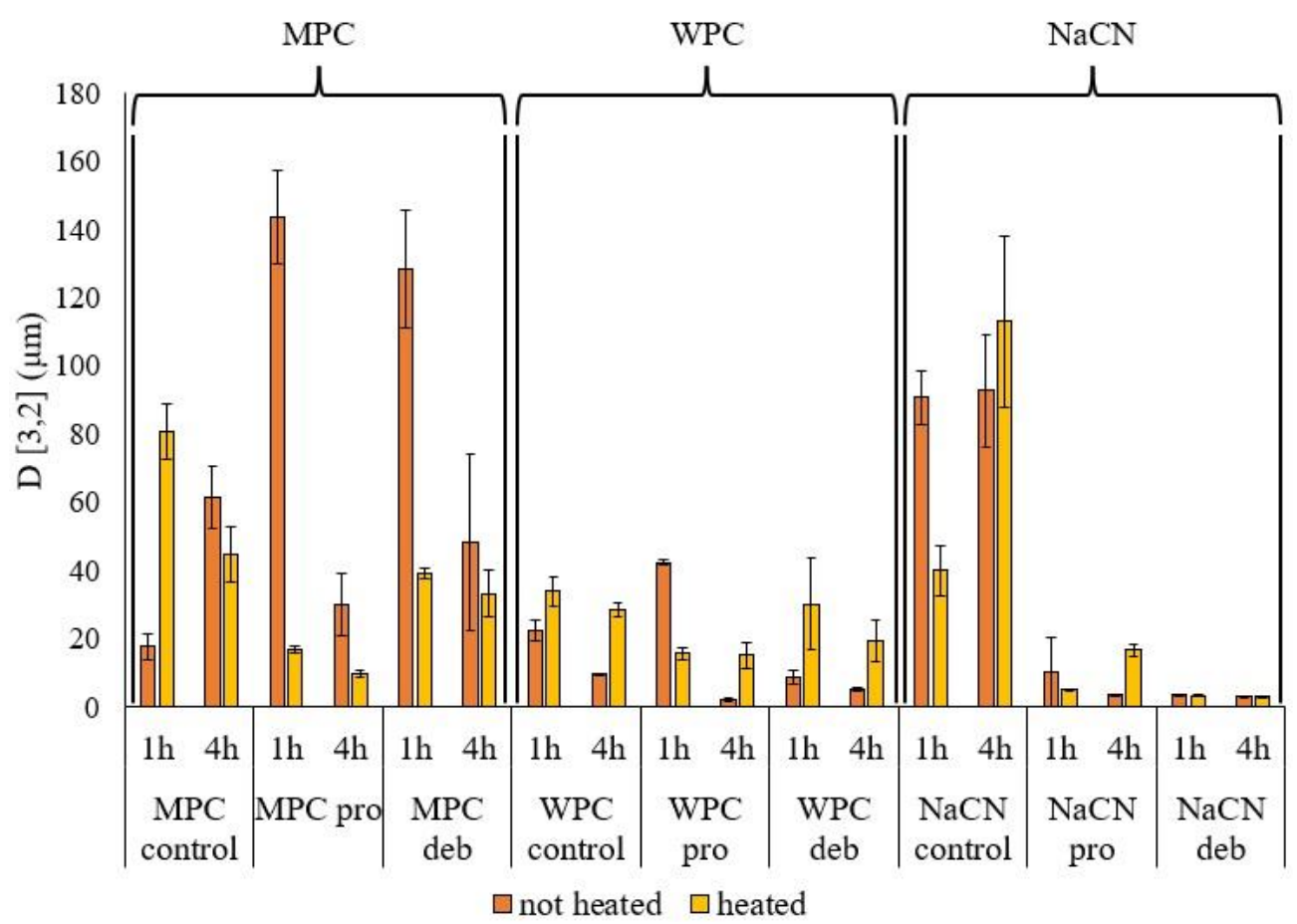

Figure 3. Particle size distribution expressed as volume moment mean diameter $D[3,2]$ for the unhydrolyzed (control) protein substrates, milk protein concentrate (MPC), whey protein concentrate (WPC) and sodium caseinate $(\mathrm{NaCN})$ and their corresponding hydrolysates generated using Prolyve $1000^{\mathrm{TM}}$ (pro) and Debitrase HYW20 ${ }^{\mathrm{TM}}$ (deb) following 1 and $4 \mathrm{~h}$ of incubation at $50{ }^{\circ} \mathrm{C}$ before (not heated) and after heat inactivation at $80^{\circ} \mathrm{C}$ for $10 \mathrm{~min}$ (heated).

\subsubsection{Turbidity}

The turbidity of protein solutions depends on protein concentration, the presence of non-dissolved particles, the particle size and particle number per volume unit [51]. Turbidity analysis of the samples, expressed as absorbance at $550 \mathrm{~nm}$ (Figure 4), indicated that the presence of aggregates (as confirmed by the particle size as measured using light scattering, seen in Figures 3 and A1) increased the turbidity of $\mathrm{NaCN}$ after hydrolysis, as reported by Ewert et al. [52], while for WPC and MPC, the turbidity decreased after hydrolysis. The heat inactivation treatment significantly increased the turbidity of unhydrolyzed whey protein concentrate and the whey protein hydrolysate (WPH) generated using Debitrase after $1 \mathrm{~h}$ of hydrolysis. This could be attributed to the fact that Debitrase is an exopeptidase containing preparation, which at low $\mathrm{DH}$, resulted in the formation of low molecular mass compounds, though there was still a significant amount of intact protein present $(\sim 30 \%)$, as shown in Figure 2. This result was further confirmed on SDS PAGE analysis (Figure A2), where a band of intact $\beta$-lactoglobulin was evident. Previous research has shown that the presence of $\beta$-lactoglobulin $(\beta-\mathrm{lg})$ could lead to the formation of heat-induced aggregates, which in turn contribute to increased turbidity [31]. 


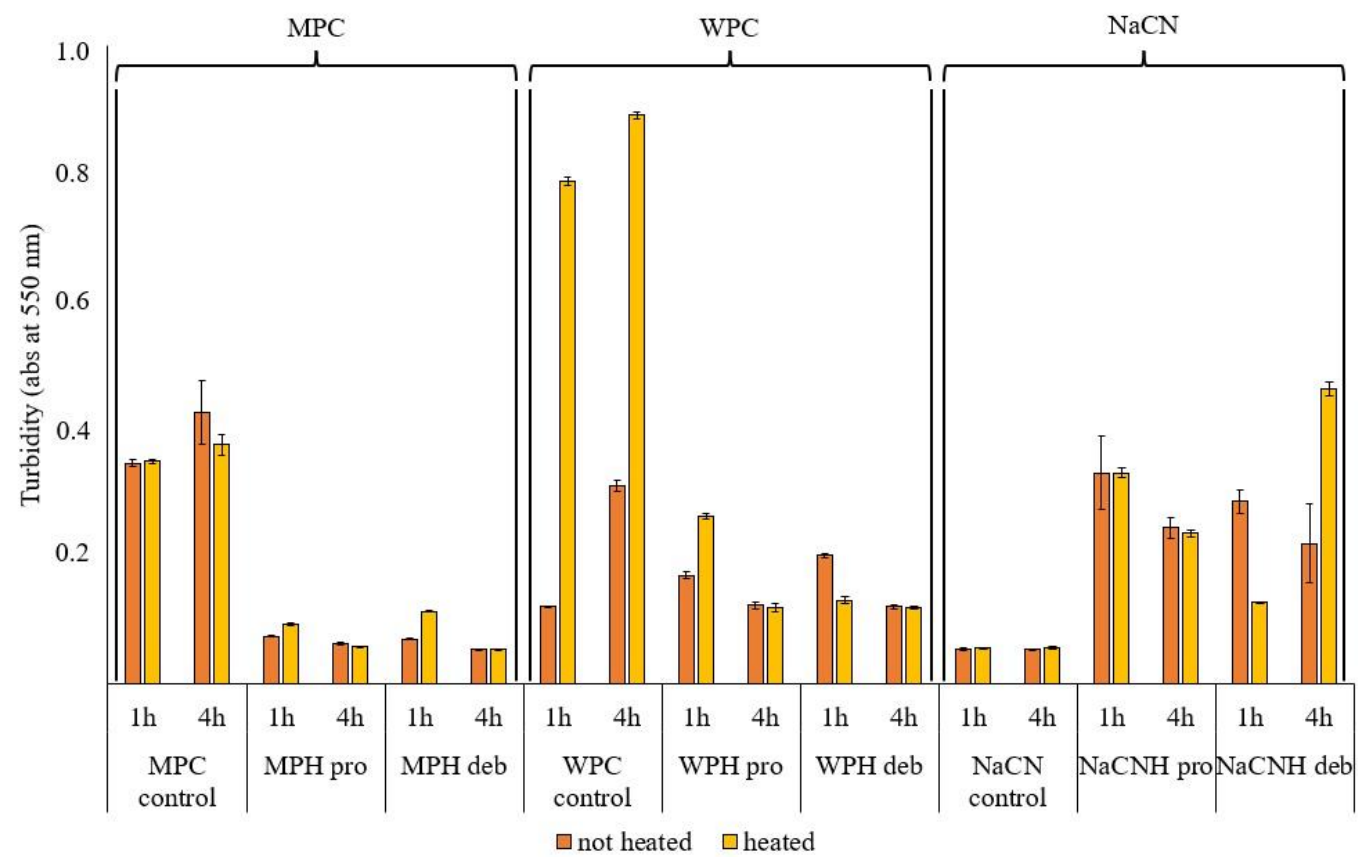

Figure 4. Turbidity expressed as absorbance at $550 \mathrm{~nm}$ for unhydrolyzed milk protein concentrate (MPC control), whey protein concentrate (WPC control) and sodium caseinate (NaCN control) control samples and their corresponding hydrolysates $(\mathrm{H})$ incubated with Prolyve $1000^{\mathrm{TM}}$ (Pro) (MPH pro, WPH pro, NACNH pro) and Debitrase HYW20" after 1 and $4 \mathrm{~h}$ of incubation at $50{ }^{\circ} \mathrm{C}$ before (not heated) and after heat inactivation at $80{ }^{\circ} \mathrm{C}$ for 10 min (heated).

In the case of the WPH generated with Prolyve, heating had no impact on the turbidity in the $4 \mathrm{~h}$ hydrolysates, while at low DH (after $1 \mathrm{~h}$ of incubation), there was a decrease in turbidity with heating. This is an indication that there were no aggregates in the hydrolysate after heating, which corroborates further the findings from the particle size distribution analysis (Figure 3). The absence of aggregates, herein, is in agreement with Spellman et al. [38], who showed no aggregation in the WPHs generated using Prolyve in contrast to those generated with Alcalase, which is a Bacillus licheniformis enzyme preparation that has been reported to lead to WPC hydrolysate aggregation. Heating only affected the turbidity of unhydrolyzed WPC, as heating of whey at $80{ }^{\circ} \mathrm{C}$ can lead to aggregation, due to the presence of $\beta-\mathrm{lg}$, which is subject to thermal denaturation and, consequently, the formation of aggregates [53]. SDS PAGE analysis (Figure A2) showed that $\beta-\mathrm{lg}$ was hydrolysed extensively in the case of the WPH generated using Prolyve, and this could be the reason why heat inactivation did not increase the turbidity of these hydrolysates.

In the case of MPC, turbidity was lower for the hydrolysates compared to intact MPC. After $4 \mathrm{~h}$ of hydrolysis, where highest DH was observed, the turbidity was lower, regardless of the enzyme used, possibly due to the low percentages of high molecular weight components, an indication that the intact protein had been hydrolysed (Figure 2). At low DH (after $1 \mathrm{~h}$ of incubation), the turbidity was affected by the inactivation treatment for both enzymes. Interestingly, there was a small increase in turbidity for the Prolyve MPC hydrolysates and a larger increase for the Debitrase MPC hydrolysates, which may be explained by the higher percentage of high MW components in Debitrase vs. Prolyve hydrolysates after $1 \mathrm{~h}$ incubation, as seen in Figure 2 (13.8\% vs. 4.2\%, respectively).

In the case of $\mathrm{NaCN}$ hydrolysates, turbidity increased for the hydrolysates compared to the unhydrolyzed control samples. This was also evident from the particle size distribution profiles (Figure A1), showing that the particle sizes increased for the hydrolysates generated using Prolyve, which could be due to the formation of aggregates. However, the significant increase in turbidity of the heated $4 \mathrm{~h}$ hydrolysates generated using Debitrase cannot be 
explained, taking into consideration the particle size distribution and the particle size of these samples, as seen in Figures 3 and A1, respectively. This increase in turbidity could, however, be due to changes in solubility.

Changes in turbidity and particle size are indicative of the presence of aggregates or a decrease in solubility, which could be the case for the sodium caseinate hydrolysates $(\mathrm{NaCNH})$ herein. Previous research has shown a decreased nitrogen solubility index at pH 7.0 for NaCN hydolysates generated using Protamex, a Bacillus proteinase, at low $\mathrm{DH}$ [14]. Low solubility at pH 6.0 and 7.0 (in the current study, all analyses were conducted at $\mathrm{pH} 7$ ) was observed for $\mathrm{NaCNHs}$ generated with different enzymes [26,54]. As described by Flanagan and FitzGerald [14], this low solubility of the hydrolysates, compared to the intact protein, could be attributed to the formation of peptides with different pIs. High turbidity, due to low solubility, can affect the further processing of hydrolysates, which need, e.g., to be pumped and spray dried. Moreover, this can affect the food products that contain them, such as in the case of juices, or beverages in general, where turbidity can impact consumer acceptability [55]. Moreover, in the case of yoghurts, the presence of large protein aggregates could result in the formation of products with low storage moduli, yield stress, firmness and thickness [56], or could lead to the gelation of acid milk gels, as described by Gélebart et al. [57].

\subsubsection{Apparent Viscosity}

Figure 5 represents the findings on the $\eta_{\text {app }}$ for the different samples. A decrease in viscosity after enzymatic hydrolysis has been widely demonstrated for most substrates in previous research $[58,59]$. The hypothesis that hydrolysis leads to a decrease in $\eta_{\text {app }}$ has been confirmed for WPC and NaCN (Figure 5). A higher decrease in $\eta_{a p p}$, compared to in MPC and WPC hydrolysates, was observed for the NaCN hydrolysates, for both enzymes used, while there were no significant differences in $\eta_{\text {app }}$ of the MPC hydrolysate compared to the original MPC. In the case of $\mathrm{NaCN}$, previous research reported a decrease in the apparent viscosity of hydrolysates having $\mathrm{DH}$ values $~ 10 \%$, compared to intact $\mathrm{NaCN}$ [14]. The viscosity of $\mathrm{NaCN}$ and its hydrolysates generated using a Bacillus proteinase differed significantly at $\mathrm{pH}$ values close to the isoelectric point $(\mathrm{pH}=4.0)$, while in the current study, all samples were tested at $\mathrm{pH}$ 7.0. In the case of whey proteins, previous studies observed gel formation of whey after limited hydrolysis with a Bacillus licheniformis protease [60], on extensive hydrolysis [61] or on heat treatment of whey protein hydrolysates [31]. However, this was not the case in the current study, where Prolyve, a Bacillus licheniformis enzyme, which does not induce gelation, was used [35].

Heating also had no effect on the viscosity of the WPC and $\mathrm{NaCN}$ hydrolysates, regardless of enzyme and incubation time. This is an important result, considering that an enzyme inactivation step, typically by heating, is required before the hydrolysates can be further processed. While careful control of the viscosity is important for processing, it is also of relevance for the application of hydrolysate ingredients in a range of products. Maintaining low viscosity can enhance heat and mass transfer during subsequent hydrolysate processing steps, such as pumping, concentration and drying. In terms of final product characteristics, careful control of the viscosity may lead to the development of desirable mouthfeel and textural properties.

In relation to $\mathrm{MPC}$ at low $\mathrm{DH}$, the $\eta_{\text {app }}$ increased after heat inactivation, while there were no significant differences in $\eta_{\text {app }}$ after heating of the 4 h-hydrolysates regardless of the enzyme used. This could partly be explained by the molecular mass distribution profile shown in Figure 2 where in the case of $1 \mathrm{~h}$ incubation there was a significant amount of intact protein remaining compared to that in the $4 \mathrm{~h}$ hydrolysates. These results are in line with the MPH turbidity findings, as seen in Figure 4. 


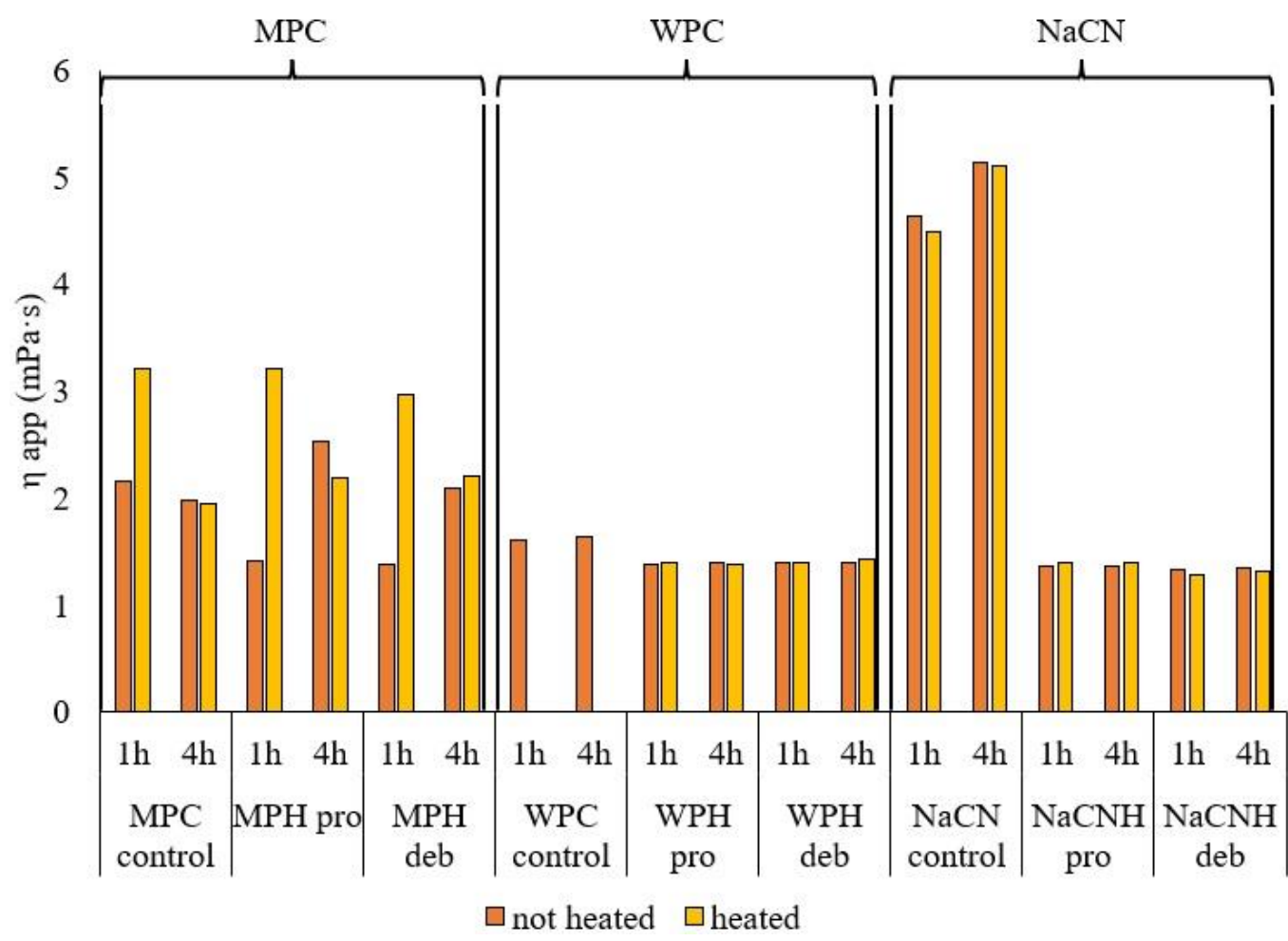

Figure 5. Apparent viscosity ( $\eta$ app) in $\mathrm{mPa} \cdot \mathrm{s}$, measured at a shear rate of $122 \mathrm{~s}^{-1}$, of unhydrolyzed milk protein concentrate (MPC control), whey protein concentrate (WPC control) and sodium caseinate $(\mathrm{NaCN}$ control) control samples and their corresponding hydrolysates $(\mathrm{H})$ before (no heated) and after heating at $80{ }^{\circ} \mathrm{C}$ for $10 \mathrm{~min}$ (heated). Hydrolysates were generated using Prolyve $1000^{\mathrm{TM}}$ (pro) and Debitrase HYW20 ${ }^{\mathrm{TM}}$ (deb) after 1 and $4 \mathrm{~h}$ of incubation at $50^{\circ} \mathrm{C}$. Note: WPC unhydrolyzed control gelled on heating; therefore, the $\eta_{\text {app }}$ could not be measured.

Since no previous studies have been conducted on the hydrolysis of MPC with Debitrase or Prolyve, the findings of the current study may only be discussed in relation to a study testing the hydrolysis of MPI using different enzymes [24]. Ryan et al. [24], who studied the changes in $\eta_{\text {app }}$ for hydrolysates of milk protein isolate, at three different temperatures $\left(25,45\right.$ and $\left.90{ }^{\circ} \mathrm{C}\right)$ and three different $\mathrm{pH}$ values $(6.2,6.8$ and 7.2). These authors reported an effect of temperature and $\mathrm{pH}$ on $\eta_{\text {app }}$. Moreover, the changes observed depended on the DH of the hydrolysates, which ranged from 15 to $37 \%$, while the highest DH achieved in the current study with MPC was 15\% (Table 1). It is difficult to compare the apparent viscosities of the current study with the findings of Ryan et al. [24], because of the different enzymes used and the different $\mathrm{pHs}$ at which the viscosity was measured. However, at lower DH, in the present study, we observed a decrease in $\eta_{\text {app }}$ of MPH compared to MPC. Heating at $80^{\circ} \mathrm{C}$ for 10 min resulted in an increase in $\eta_{\text {app }}$, possibly due to a decreased heat stability (as reported by Ryan et al. [24], between $\mathrm{pH} 6.2$ and 7.4), possibly due to changes in casein micelle structure. These changes may be linked to the observed changes in turbidity. Further hydrolysis $(4 \mathrm{~h})$ increased the viscosity of the unheated MPC hydrolysates. However, heating did not alter the viscosity of these samples. The $\eta_{\text {app }}$ in this case for the heat-treated samples was measured after the samples were heated at $80{ }^{\circ} \mathrm{C}$ and were then cooled to $50^{\circ} \mathrm{C}$, to conduct all measurements at the same temperature. This cooling step may impact the $\eta_{\text {app }}$ values, as shown by Ryan et al. [24], who reported a viscosity increase upon the cooling of milk protein isolate (MPI) control samples and low DH MPI hydrolysates, generated using a variety of enzymes (i.e., by $\sim 15 \%$ with Neutrase and Flavourzyme and by $17 \%$ with Protamex). 


\section{Conclusions}

The current study explored the impact of hydrolysis conditions, such as enzyme preparation, incubation time and heat inactivation, on the physicochemical properties of hydrolysates, generated from different milk protein substrates (WPC, MPC and NaCN). The two enzymes used, Debitrase and Prolyve, were chosen on the basis that they may lead to the generation of hydrolysates with reduced bitterness. Following $1 \mathrm{~h}$ incubation, the degree of hydrolysis was higher for $\mathrm{NaCN}$ compared to the other substrates and, while there was no enzyme effect on the DHs of WPC and MPC hydrolysates, hydrolysis with Debitrase resulted in a higher $\mathrm{DH}$ for $\mathrm{NaCN}$. The effect of hydrolysis on the physicochemical properties depended on the substrate. For example, $\eta_{\text {app }}$ decreased in WPC and NaCN hydrolysates, particle size decreased for all the substrates, with aggregate formation for MPC, and turbidity decreased in WPC and MPC hydrolysates but increased in NaCN hydrolysates. Viscosity, turbidity and particle size changes were substrate- and incubation time-dependent and, to a lesser extent, also enzyme-dependent. Heat inactivation, an essential step during the processing of hydrolysates, impacted the hydrolysate physicochemical properties in different ways, depending on both the $\mathrm{DH}$ and the starting substrate. At longer incubation times, which also resulted in higher DHs, heat inactivation of the hydrolysates did not significantly impact the turbidity and viscosity of the hydrolysates, which is of significant industrial importance, when considering the further processing of hydrolysates. The findings reported herein, may help in the design of enzymatic processing approaches for the generation of hydrolysate ingredients from different milk protein starting substrates.

Author Contributions: Conceptualization, R.J.F., M.D. and G.S.; methodology, R.J.F., M.D., A.G. and G.S.; formal analysis, A.G. and M.D.; resources, R.J.F. and G.S.; data curation, A.G., M.D. and G.S.; writing—original draft preparation, A.G. and M.D.; writing-review and editing, R.F and G.S.; supervision, R.J.F. and G.S.; funding acquisition, R.J.F. and G.S. All authors have read and agreed to the published version of the manuscript.

Funding: This research received no external funding.

Institutional Review Board Statement: Not applicable.

Informed Consent Statement: Not applicable.

Data Availability Statement: The data that support the findings of this study are available from the corresponding author upon reasonable request.

Acknowledgments: This research was supported by Doctoral School on the Agro-Food System of the Università Cattolica del Sacro Cuore (PhD grantship from Fondazione di Piacenza e Vigevano to Alice Gruppi, XXXII cycle).

Conflicts of Interest: The authors declare no conflict of interest.

\section{Appendix A}

SDS polyacrylamide gel electrophoresis (SDS PAGE): For determination of the electrophoretic profile, the samples (hydrolysates and unhydrolyzed control after heat inactivation) were resuspended in a solution of $1 \%(w / v)$ SDS, in order to dissociate the proteins. The sample buffer contained $\beta$-mercaptoethanol to carry out the electrophoresis under reducing conditions. The running buffer used was Tris-glycine-SDS (25 mM Tris, $192 \mathrm{mM}$ glycine and 0.1\% SDS, pH 8.6). Gels were run at a constant voltage of $150 \mathrm{mV}$ for 60 min. Mini-PROTEAN TGX precast gels (4-20\% resolving gel, Bio-Rad Laboratories Inc., Hercules, CA, USA) were used on a Mini Protean II system (Bio-Rad), according to the manufacturer's instructions. The quantity of protein added to each well was $15 \mu \mathrm{g}$. The molecular masses of the proteins were estimated by reference to the relative migration of the molecular mass standards, which had a wide range of molecular weights (6500-200,000 Da, Sigma-Aldrich, St. Louis, MO, USA). The gels were stained with Coomassie Blue R-250. 

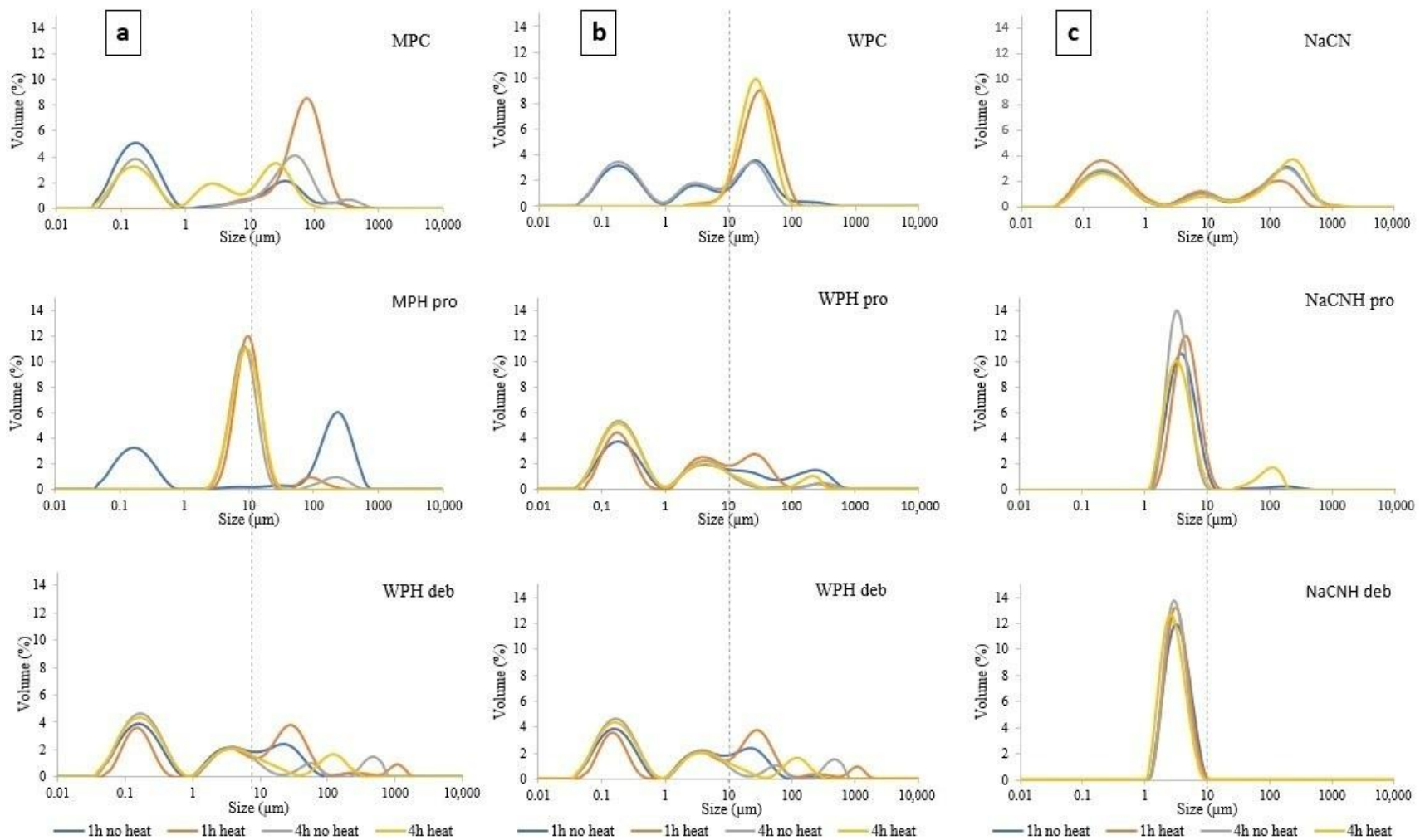

Figure A1. Particle size distribution profiles of intact protein substrates and their corresponding hydrolysates $(\mathrm{H})$. ((a): milk protein concentrate (MPC); (b): whey protein concentrate (WPC); (c): sodium caseinate $(\mathrm{NaCN})$ ) generated using Prolyve $1000^{\mathrm{TM}}$ (pro) (MPH pro, WPH pro, NaCNH pro) and Debitrase HYW20 ${ }^{\mathrm{TM}}$ (deb) (MPH Deb, WPH deb, NaCNH deb) after 1 and $4 \mathrm{~h}$ of incubation at $50^{\circ} \mathrm{C}$ before (no heat) and after heat inactivation at $80^{\circ} \mathrm{C}$ for $10 \mathrm{~min}$ (heat).
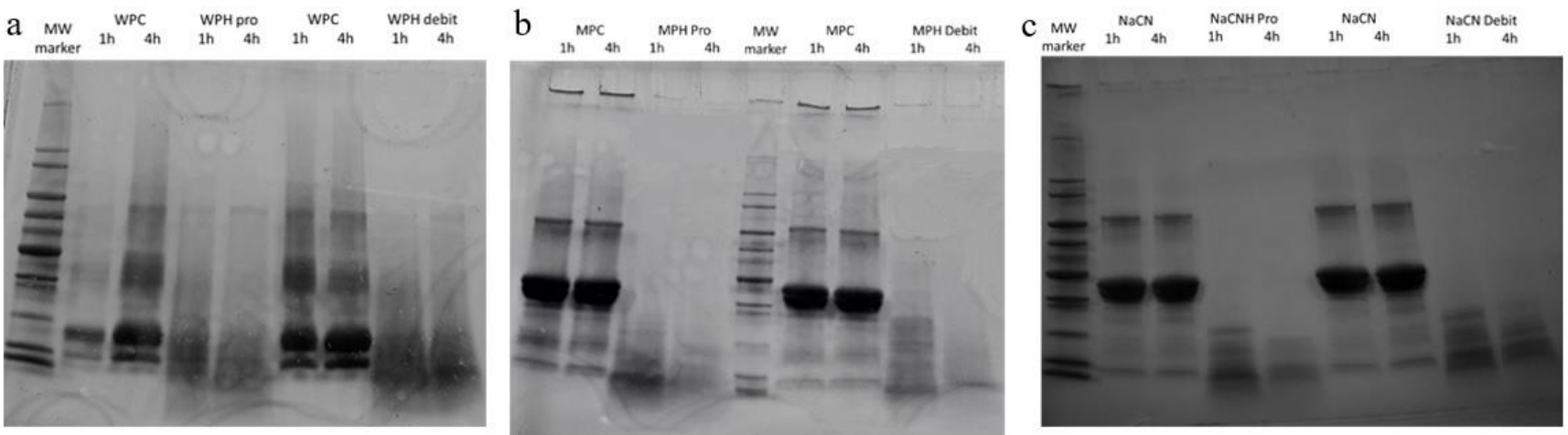

Figure A2. Sodium Dodecyl Sulphate Polyacrylamide Gel Electrophoresis (SDS page) of the intact protein and the corresponding hydrolysates. ((a): WPC; (b): MPC; (c): NaCN) generated using Prolyve (Pro) and Debitrase (Debit) after $1 \mathrm{~h}$ and $4 \mathrm{~h}$ of incubation.

\section{References}

1. Carr, A.; Golding, M. Functional milk proteins production and utilization: Casein-based ingredients. In Advanced Dairy Chemistry, 4th ed.; McSweeney, P.L.H., O’Mahony, J.A., Eds.; Springer: Cork, Ireland, 2016; Volume 1B, pp. 35-66.

2. Nongonierma, A.B.; FitzGerald, R.J. The scientific evidence for the role of milk protein-derived bioactive peptides in humans: A Review. J. Funct. Foods 2015, 17, 640-656. [CrossRef]

3. Cheison, S.C.; Kulozik, U. Impact of the environmental conditions and substrate pre-treatment on whey protein hydrolysis: A review. Crit. Rev. Food Sci. Nutr. 2017, 57, 418-453. [CrossRef]

4. Abd El-Salam, M.H.; El-Shibiny, S. Preparation, properties, and uses of enzymatic milk protein hydrolysates. Crit. Rev. Food Sci. Nutr. 2017, 57, 1119-1132. [CrossRef] 
5. Izadi, A.; Khedmat, L.; Mojtahedi, S.Y. Nutritional and therapeutic perspectives of camel milk and its protein hydrolysates: A review on versatile biofunctional properties. J. Funct. Foods 2019, 60, 103441. [CrossRef]

6. Mulvihill, D.M. Production, functional properties and utilization of milk protein products. In Advanced Dairy Chemistry Fox, P.F., Ed.; Elsevier Science Publishers: London, UK, 1992; Volume 1, pp. 369-404. [CrossRef]

7. Spellman, D.; McEvoy, E.; O'Cuinn, G.; FitzGerald, R.J. Proteinase and exopeptidase hydrolysis of whey protein: Comparison of the TNBS, OPA and pH stat methods for quantification of degree of hydrolysis. Int. Dairy J. 2003, 13, 447-453. [CrossRef]

8. Pelegrine, D.H.G.; Gasparetto, C.A. Whey proteins solubility as function of temperature and pH. LWT-Food Sci. Technol. 2005, 38, 77-80. [CrossRef]

9. Agarwal, S.; Beausire, R.L.; Patel, S.; Patel, H. Innovative uses of milk protein concentrates in product development. J. Food Sci. 2015, 80, A23-A29. [CrossRef]

10. De Castro-Morel, M.; Harper, W.J. Basic functionality of commercial milk protein concentrates. Milchwissenschaft 2002, 57, 367-370

11. Meena, G.S.; Singh, A.K.; Panjagari, N.R.; Arora, S. Milk protein concentrates: Opportunities and challenges. J. Food Sci. Technol. 2017, 54, 3010-3024. [CrossRef]

12. Khalesi, M.; FitzGerald, R.J. Insolubility in milk protein concentrates: Potential causes and strategies to minimize its occurrence. Crit. Rev. Food Sci. Nutr. 2021, 15, 1-17. [CrossRef]

13. Panyam, D.; Kilara, A. Enhancing the functionality of food proteins by enzymatic modification. Trends Food Sci. Technol. 1996, 71, 120-125. [CrossRef]

14. Flanagan, J.; FitzGerald, R.J. Functionality of Bacillus proteinase hydrolysates of sodium caseinate. Int. Dairy J. 2002, 12, 737-748. [CrossRef]

15. Tuncturk, Y.; Zorba, O. The effects of enzymatic hydrolysis of casein on apparent yield stress and some emulsion properties. Food Hydrocoll. 2006, 20, 475-482. [CrossRef]

16. De Castro, R.J.S.; Bagagli, M.P.; Sato, H.H. Improving the functional properties of milk proteins: Focus on the specificities of proteolytic enzymes. Curr. Opin. Food Sci. 2015, 1, 64-69. [CrossRef]

17. Cui, Q.; Sun, Y.; Zhou, Z.; Cheng, J.; Guo, M. Effects of enzymatic hydrolysis on physicochemical properties and solubility and bitterness of milk protein hydrolysates. Foods 2021, 10, 2462. [CrossRef]

18. Ryan, G.; Nongonierma, A.B.; O'Regan, J.; FitzGerald, R.J. Functional properties of bovine milk protein isolate and associated enzymatic hydrolysates. Int. Dairy J. 2018, 81, 113-121. [CrossRef]

19. Turgeon, S.L.; Gauthier, S.F.; Paquin, P. Interfacial and Emulsifying Properties of Whey Peptide Fractions Obtained with a Two-step Ultrafiltration Process. J. Agric. Food Chem. 1991, 39, 70-73. [CrossRef]

20. Mutilangi, W.A.M.; Panyam, D.; Kilara, A. Functional Properties of Hydrolysates from Proteolysis of Heat-denatured Whey Protein Isolate. J. Food Sci. 1996, 61, 270-274. [CrossRef]

21. Severin, S.; Xia, W.S. Enzymatic hydrolysis of whey proteins by two different proteases and their effect on the functional properties of resulting protein hydrolysates. J. Food Biochem. 2006, 30, 77-97. [CrossRef]

22. Cermeño, M.; Felix, M.; Connolly, A.; Brennan, E.; Coffey, B.; Ryan, E.; FitzGerald, R.J. Role of carbohydrate conjugation on the emulsification and antioxidant properties of intact and hydrolysed whey protein concentrate. Food Hydrocoll. 2019, 88, 170-179. [CrossRef]

23. Walsh, D.J.; Russell, K.; FitzGerald, R.J. Stabilisation of sodium caseinate hydrolysate foams. Food Res. Int. $2008,41,43-52$. [CrossRef]

24. Banach, J.C.; Lin, Z.; Lamsal, B.P. Enzymatic modification of milk protein concentrate and characterization of resulting functional properties. LWT-Food Sci. Technol. 2013, 54, 397-403. [CrossRef]

25. McIntyre, I.; Carolan, A.; O'Sullivan, M.; Jacquier, J.; Hutchings, S.; Murray, B.; O'Riordan, D. Incorporation of bioactive dairy hydrolysate influences the stability and digestion behaviour of milk protein stabilised emulsions. Food Funct. 2018, 9, 5813-5823. [CrossRef]

26. Chobert, J.; Bertrand-Harb, C.J.; Nicolas, M. Solubility and Emulsifying Properties of Caseins and Whey Proteins Modified Enzymatically by Trypsin. J. Agric. Food Chem. 1988, 36, 883-892. [CrossRef]

27. Zhao, C.; Chen, N.; Ashaolu, T.J. Whey proteins and peptides in health-promoting functions-A review. Int. Dairy J. 2021, 126, 105269. [CrossRef]

28. Le Maux, S.; Nongonierma, A.B.; Barre, C.; FitzGerald, R.J. Enzymatic generation of whey protein hydrolysates under pHcontrolled and non pH-controlled conditions: Impact on physicochemical and bioactive properties. Food Chem. 2016, 199, 246-251. [CrossRef] [PubMed]

29. Dermiki, M.; FitzGerald, R.J. Physicochemical and gelling properties of whey protein hydrolysates generated at 5 and $50{ }^{\circ} \mathrm{C}$ using Alcalase ${ }^{\circledR}$ and Neutrase ${ }^{\circledR}$, effect of total solids and incubation time. Int. Dairy J. 2020, 110, 104792. [CrossRef]

30. Le Maux, S.; Nongonierma, A.B.; FitzGerald, R.J. Peptide composition and dipeptidyl peptidase IV inhibitory properties of $\beta$-lactoglobulin hydrolysates having similar extents of hydrolysis while generated using different enzyme-to-substrate ratios. Food Res. Int. 2017, 99, 84-90. [CrossRef]

31. Spellman, D.; Kenny, P.; O'Cuinn, G.; FitzGerald, R.J. Aggregation properties of whey protein hydrolysates generated with Bacillus licheniformis proteinase activities. J. Agric. Food Chem. 2005, 53, 1258-1265. [CrossRef]

32. Adler-Nissen, J. Control of the Proteolytic Reaction and of the Level of Bitterness in Protein Hydrolysis Processes. J. Chem. Technol. Biotechnol. 1984, 34, 215-222. [CrossRef] 
33. Rajarathnam, E.; Nongonierma, A.B.; O'Sullivan, D.; Flynn, C.; FitzGerald, R.J. Impact of enzyme preparation and degree of hydrolysis on peptide profile and nitrogen solubility of sodium caseinate hydrolysates. Int. J. Food Sci. Technol. 2016, 51, 2123-2131. [CrossRef]

34. Le Maux, S.; Nongonierma, A.B.; Lardeux, C.; FitzGerald, R.J. Impact of enzyme inactivation conditions during the generation of whey protein hydrolysates on their physicochemical and bioactive properties. Int. J. Food Sci. Technol. 2018, 53, $219-227$. [CrossRef]

35. Nongonierma, A.B.; FitzGerald, R.J. Tryptophan-containing milk protein-derived dipeptides inhibit xanthine oxidase. Peptides 2012, 37, 263-272. [CrossRef] [PubMed]

36. O'Loughlin, I.B.; Murray, B.A.; Kelly, P.M.; FitzGerald, R.J.; Brodkorb, A. Enzymatic Hydrolysis of Heat-Induced Aggregates of Whey Protein Isolate. J. Agric. Food Chem. 2012, 60, 4895-4904. [CrossRef] [PubMed]

37. Addinsoft. XLSTAT Statistical and Data Analysis Solution 2020. New York, NY, USA. Available online: https://www.xlstat.com (accessed on 16 May 2020).

38. Spellman, D.; O'Cuinn, G.; FitzGerald, R.J. Physicochemical and sensory characteristics of whey protein hydrolysates generated at different total solids levels. J. Dairy Res. 2005, 72, 138-143. [CrossRef] [PubMed]

39. FitzGerald, R.J.; O'Cuinn, G. Enzymatic debittering of food protein hydrolysates. Biotechnol. Adv. 2006, 24, 234-237. [CrossRef]

40. Whitehurst, R.J.; Van Oort, M. Enzymes in Food Technology, 2nd ed.; Wiley Blackwell: Singapore, 2009.

41. Power, O.; Jakeman, P.; FitzGerald, R.J. Antioxidative peptides: Enzymatic production, in vitro and in vivo antioxidant activity and potential applications of milk-derived antioxidative peptides. Amino Acids 2013, 44, 797-820. [CrossRef]

42. Svendsen, I.; Breddam, K. Isolation and amino acid sequence of a glutamic acid specific endopeptidase from Bacillus licheniformis Eur. J. Biochem. 1992, 204, 165-171. [CrossRef]

43. Nongonierma, A.B.; FitzGerald, R.J. Enzymes exogenous to milk in dairy technology. Proteinases. In Encyclopedia of Dairy Science, 2nd ed.; Fuquay, J.W., Fox, P.F., Mc Sweeney, P.J.H., Eds.; Academic Press: San Diego, CA, USA, 2011; pp. $289-296$.

44. McDonagh, D.; FitzGerald, R.J. Production of caseinophosphopeptides (CPPs) from sodium caseinate using a range of commercial protease preparations. Int. Dairy J. 1998, 8, 39-45. [CrossRef]

45. Bhandari, D.; Rafiq, S.; Gat, Y.; Gat, P.; Waghmare, R.; Kumar, V. A review on bioactive peptides: Physiological functions, bioavailability and safety. Int. J. Pept. Res. Ther. 2020, 26, 139-150. [CrossRef]

46. Adjonu, R.; Doran, G.; Torley, P.; Agboola, S. Whey protein peptides as components of nanoemulsions: A review of emulsifying and biological functionalities. J. Food Eng. 2014, 122, 15-27. [CrossRef]

47. Ding, Y.; Chen, L.; Shi, Y.; Akhtar, M.; Chen, J.; Ettelaie, R. Emulsifying and emulsion stabilizing properties of soy protein hydrolysates, covalently bonded to polysaccharides: The impact of enzyme choice and the degree of hydrolysis. Food Hydrocoll. 2021, 113, 106519. [CrossRef]

48. Karami, Z.; Akbari-Adergani, B. Bioactive food derived peptides: A review on correlation between structure of bioactive peptides and their functional properties. J. Food Sci. Technol. 2019, 56, 535-547. [CrossRef] [PubMed]

49. Morais, H.A.; Silvestre, M.P.C.; Viviane, D.M.; Mauro, R.S.; Silva, A.S.; Silvera, J.N. Correlation between the degree of hydrolysis and the peptide profile of whey protein of hydrolysis and peptide profile of whey protein concentrate hydrolysate: Effect of the enzyme type and reaction time. Am. J. Food Technol. 2013, 8, 1-16. [CrossRef]

50. Gani, A.; Broadway, A.A.; Ahmad, M.; Ashwar, B.A.; Wani, A.A. Enzymatic hydrolysis of whey and casein protein- effect on functional, rheological, textural and sensory properties of breads. J. Food Sci. Technol. 2015, 52, 7697-7709. [CrossRef] [PubMed]

51. Mahler, H.; Friess, W.; Grauschopf, U.; Kiese, S. Protein Aggregation: Pathways, Induction Factors and Analysis. J. Pharm. Sci. 2008, 98, 2909-2934. [CrossRef]

52. Ewert, J.; Luz, A.; Volk, V.; Stressler, T.; Fischer, L. Enzymatic production of emulsifying whey protein hydrolysates without the need of heat inactivation. J. Sci. Food Agric. 2019, 99, 3443-3450. [CrossRef]

53. Iametti, S.; De Gregori, B.; Vecchio, G.; Bonomi, F. Modifications occur at different structural levels during the heat denaturation of $\beta$-lactoglobulin. Eur. J. Biochem. 1996, 237, 106-112. [CrossRef]

54. Slattery, H.; Fitzgerald, R.J. Functional Properties and Bitterness of Sodium Caseinate Hydrolysates Prepared with a Bacillus Proteinase. J. Food Sci. 1998, 63, 418-422. [CrossRef]

55. Nam, S.-H.; Wagh, A.; Martini, S.; Walsh, M.K. Sensory characterisation of a high-protein beverage. Int. J. Dairy Technol. 2017, 70, 432-438. [CrossRef]

56. Lesme, H.; Rannou, C.; Loisel, C.; Famelart, M.H.; Bouhallab, S.; Prost, C. Controlled whey protein aggregates to modulate the texture of fat-free set-type yoghurts. Int. Dairy J. 2019, 92, 28-36. [CrossRef]

57. Gélébart, P.; Riaublanc, A.; Famelart, M.H.; Jonchère, C.; Beaumal, V.; Anton, M.; Garnier, C. Protein aggregates modulate the texture of emulsified and acidified acid milk gels. Food Hydrocoll. 2019, 93, 176-188. [CrossRef]

58. Jung, S.; Murphy, P.A.; Johnson, L.A. Physicochemical and Functional Properties of Soy Protein Substrates Modified by Low Levels of Protease Hydrolysis. J. Food Sci. 2006, 70, C180-C185. [CrossRef]

59. Diniz, F.M.; Martin, A.M. Effects of the Extent of Enzymatic Hydrolysis on Functional Properties of Shark Protein Hydrolysate. LWT-Food Sci. Technol. 1997, 30, 266-272. [CrossRef] 
60. Ju, Z.Y.; Otte, J.; Madsen, J.S.; Qvist, K.B. Effects of limited proteolysis on gelation and gel properties of whey protein isolate. J. Dairy Sci. 1995, 78, 2119-2128. [CrossRef]

61. Otte, J.; Ju, Z.Y.; Skriver, A.; Qvist, K.B. Effects of limited proteolysis on the microstructure of heat-induced whey protein gels at varying pH. J. Dairy Sci. 1996, 79, 782-790. [CrossRef] 